\title{
PHILOSOPHY OF EDUCATION AND PEDAGOGY: SUBJECT STATUS
}

\author{
АшилОвА \\ Мадина \\ Серикбековна
}

\author{
БЕГАЛИНОВ \\ Алибек
}

\section{БЕГАЛИНОВА Калимаш}

\author{
доктор PhD, кандидат философских наук, \\ ассоциированный профессор, \\ мировых языков имени Абылай хана, кафедра \\ медиакоммуникации, \\ Алматы, Казахстан, madina.almatytv@gmail.com

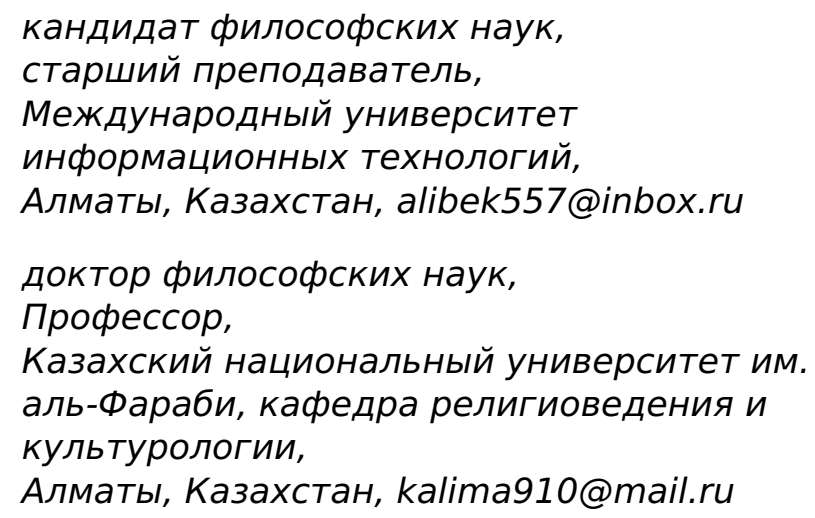
Казахский университет международных отношений и

(c) 2020 Петрозаводский государственный университет

\section{PHILOSOPHY OF EDUCATION AND PEDAGOGY: SUBJECT STATUS}

Introduction. National philosophy of education as an interdisciplinary and integrative science originating from the end of the XX century, when the native philosophers following the Western scientists understood the need of the philosophical reflection of the educational processes. Undoubtedly, the origins of its formation originate from an earlier time. The junction of the XIX and the XX centuries saw an objective, cultural and ideological need in the creation and development of the philosophical aspects of education. This feature, in due course time, was noticed by V. V. Rozanov. He was one of the first (1899) to use the term "philosophy of education" and gave it the following definition: "We have didactics and number of didactics, we have pedagogy in general as theory of some craft, art or something. But we did not have and do not have anything that could be called the philosophy of education and upbringing, i.e., the discussion of the education itself, upbringing itself in a number of other cultural factors and also with regard to the eternal patterns of human nature and constant challenges of history" [1, p. 601]. It seems to us that the idea of V.V. Rozanov acted as an impetus for research in this particular philosophical direction.

Methodology of scientific research. The methodological basis of the study was the sociocultural approach, the essence of which is to consider education as the main sphere of social activity. The modern education is influenced by the dynamic sociocultural transformations that apply to all spheres of life and personal needs.So, the authors used value semantic, managerial and organizational methods, systems analysis and general philosophical methods for this research.

Results and discussion. There is a number of approaches to the philosophy of education that include, 
for example, the following definitions: "Philosophy of education is a special type of philosophical systemacy specializing in the field of education» (Encyclopedia Britannica); «Philosophy of education is a way of thinking about education» (Ya. Boyce); "Philosophy of education is a therapy of a man, making of a human in a person, keeping the plan of integrity of their "image"; "Philosophy of education is a sphere of interprofessional productive dialogue between various scientists ... specializing in the field of education" [2]. The sphere of scientific competence of the philosophy itself (general philosophy) is comprised of the universal laws of the human, society and nature existence. Turning to education, the philosophy applies a high level of abstraction and analysis of the conceptual level. In essence, it studies the universal laws in the field of education. S. Sharms in the work Philosophical Foundations of Education (1969) pointed out that the concept of education introduced into the structure of the philosophy of education in terms of its abstraction should not be lower than the concept of "knowledge" [3, p. 8]. The concept of the "philosophy of education" itself should be introduced to the system of concepts of the "branch" philosophy and perform a heuristic role in the analysis of education at a level of system-based organized movement of concepts. In the Russian language, the concept of "education" originates from two concepts: "image" and "to form". In terms of terminology, "image" means a well-defined outline of a certain object or a phenomenon. "To form" means to take some actions to develop a relevant image. From this perspective, terminologically, "education" can be defined as a process of making or forming an image corresponding to the time requirements. But terminological perspective gives us just a general idea of the concept. However, there is a diversity of opinions in determining the essence of this concept. In the pedagogical literature, the concept of "education" refers primarily to the process of the transfer and acquisition of knowledge and skills, and the formation of cognitive interests and abilities, to the special training in professional activity [4]. Moreover, these processes are performed not in isolation but within the bonds that are determined by the principle of unity of education and upbringing. Education, being solely a multidimensional concept, reflects the process of people's socialization, including the process and the result of knowledge and skills acquisition that affect the "image" of a person corresponding to the social demands. The philosophical significance of the concept lies in the emphasis on the formation of a person, his or her socialization. Education as a system of people's socialization is a deep interrelation of pedagogy, education, upbringing and enlightenment. The authors of a textbook Pedagogy: Pedagogical Theories, Systems, Technologies write that the "connection between philosophy and pedagogy has a dual character. Sometimes pedagogy was recognized as a "testing ground" for the application and approbation of philosophical ideas. In this case it was considered "practical philosophy" [5]. As for the correlation between philosophy and philosophy of education, one of the most commonly expressed opinions is that philosophy of education is an applied philosophical discipline, since the general principles and provisions of the philosophy are applied to analyze the various aspects of education, which, in turn, is considered to be a process, an activity, a system, a value and a social institution. The word "application" is contextually used to indicate what "is applied, and not "to what is applied" [6]. And in this context, the applied is not the philosophy of education, but philosophy itself. We believe that the very meaning of the term "applied" is used to indicate the goal of science, the application of scientific knowledge to practice. But the philosophy of education, in its essence, represents a system-based vision of the educational objectivity to the sectoral sciences (in our case - pedagogy, theory of upbringing, enlightenment and education). Thus, in our view, the philosophy of education should be rightly considered a branch of philosophy or a section of social philosophy posing and solving philosophical problems in the social sphere of life. In this case, the philosophy of education is not just a science, but a doctrine which organically includes the scientific, ethical, aesthetic, axiological, ontological, epistemological and other aspects. In the process of development, the philosophy of education as a doctrine and a scientific direction is equally deeply connected with philosophy in general and with the sectoral sciences. Philosophy of education is a link between the universal (the theory of the highest level of abstraction) and the specific (educational activity). However, in the literature on the theory of pedagogy and in the tutorials not so much attention is given, unfortunately, to the problem of philosophical understanding of education. For example, in a pedagogical textbook Pedagogy edited by P. I. Pidkasistiy only one paragraph focuses specifically on such an important problem as the interaction between philosophy and pedagogy: "The most productive factors of progress of the pedagogic science should include its interrelations with philosophy. In it the science of education finds, in particular, the supporting methodological positions. Philosophical categories of necessity and contingency, common, singular and special; the laws of interrelation and interdependence, the laws development and its driving forces, the subjective and objective determinism of pedagogical phenomenon and many others. Such sections of philosophy as materialist dialectics and theory of knowledge (epistemology) also make contribution to the development of research thinking. In connection with the deepening of philosophical understanding of various aspects of the reality the branch philosophies are developed as well. The philosophy of education, philosophy of culture, philosophy of history, philosophy of law, philosophy of science 
and others obtain the status of branches of knowledge. And as pedagogic science is developing in conjunction with other human sciences, the addressing to their philosophy contributes to its success" [7, p. 10]. It would be unfair to accuse the authors of this textbook and other theorists of pedagogy of rejecting the philosophical understanding, or of such short covering of the problems of interaction between philosophy and the theory of education and pedagogy. As has been already noted, there was no tradition of philosophical understanding of education, and the current level of development of the philosophy of education itself so far has not enabled to do it more carefully and in detail, although it should be noted that it has already had an experience of such consideration. As a rule, the philosophical approaches can be found in the studies of the educational process and the theory of pedagogy in the philosophical and methodological grounds of humanization of education (for example, in the works of T. A. Rubantsova) and in the works on the philosophy of education in the humanities (N. S. Rozov), as has been mentioned above. These authors, on the basis of the history of philosophy and the history of pedagogy, are tracing the genesis of philosophical and pedagogical thought and provide an overview of contemporary foreign and national researches on the philosophy of education. For example, T. A. Rubantsova, in her doctoral dissertation Philosophical and Methodological Foundations of Humanization of Education and in her monographs covers philosophy, culture and education by outlining the problem field. She rightly points out that philosophy classifies the accumulated human life experience, reduces all aspects of reality to integrity that determine the human perception of the world, their understanding and experience, while in education the mechanisms of vital life sustenance, socialization of personality, and preparation for objective reality in contemporary culture are formed. Education is a way of acculturation and enculturation of personality, it creates an individual of a new culture of the future. "The mankind faced with the new challenges of survival at the end of the XX century does not have much time for reflection. It cannot continue its development using the old routes, embodied in the cultural matrix of industrial civilization, and education plays a leading role in this process. The study of the problem of humanization of education in terms of the socio-philosophical approach, will allow not only to identify the already existing links, but also to actively participate in the search for the orientations for the future" [8, p.177]. Thus, the analysis of the philosophy of education requires the reference to pedagogy as a science, where information, facts, and processes are linked by an internal, organic necessity of the scientific method, and scientific knowledge is represented as organized system. Science, including pedagogy, is developing in accordance with its laws, the inner necessity of its inherent method. In the theory of pedagogy, as well as in other sciences, it (science) exists only where "the researcher explores for the sake of knowledge, freely questioning the nature" [8, p. 36]. It was the close relationship between philosophy and the theory of education that forced S. I. Hessen to call pedagogy an applied philosophy. He drew particular attention to the close relationship between the history of pedagogy and the history of philosophy: “... Let's have a few considerations ... on the close link between the philosophy and pedagogy ... If pedagogy is so closely associated with the philosophy and, in a sense, even can be called an applied philosophy, then it should be expected that the history of pedagogy is a part - or, if you like, a reflection - of the history of philosophy. And it is really so. Plato, Locke, Rousseau, Spencer - all these names belong not only to the reformers of pedagogy, but also to the representatives of philosophical thought. Pestalozzi was only the distinctive mouthpiece in the pedagogy of that coup, which in his contemporary philosophy was made by criticism, in particular, of Kant, as recognized by all was a reflection of the principles of Shelling's philosophy in pedagogy. ... Drawing its guidelines, and, above all, breaking-up from the philosophy, pedagogy mostly reflects on itself as the development of philosophical thought" [8, p.36-37]. Thus, the upper level of the theory of pedagogy is deeply connected with the philosophical understanding of its subject, the reflection of the principles of certain philosophical concept in the various pedagogic theories. Thus, we raise a question that the philosophy of education includes two organically interconnected parts, two methodological levels: one is primarily addressed to the general philosophy, and the other - to education.

Conclusions. In general, in the analysis of the "philosophy of education" concept, we are highlighting the following aspects. Firstly, it can act in one or another form of the philosophical conceptualization of education; secondly, it can itself be an object of philosophical analysis; and thirdly, the philosophy of education can be understood as a practical philosophy of education, without strict and rationally expressed conceptual systems. When the "philosophy of education" is the object of study, it inevitably includes its first and third aspects. Therefore, we strongly believe that the philosophy of education is always concrete, subjective, and thus shaped by history and determined. One more time it is necessary to underline the variety of the subject areas of education as the research object, since it predetermines the fundamental integrity and interdisciplinarity of the philosophy of education. In this situation of spiritual impoverishment, total educational crisis, and degradation of all aspects of human life, the national system of education faces a major problem: to find a new form of existence, which would allow the education not only to survive, but also to strengthen its 
status of the main mechanism of social reproduction and development, and achieve it in a very short time, with minimal resources, amid unfavorable sociocultural environment and the collapse of the traditional educational system. In this context, the philosophy of education is of great importance. "The scientific, world outlook level of educational policy, strategy, and tactics of the educational systems development would depend on the degree of development of the philosophy of education" [9, p. 38]. Therefore, the emphasis of the modern philosophy of education should be made on the development of a new methodology, more comprehensive methodological tools (ontology, axiology, praxeology), which would allow to find common grounds for the modern educational system and pedagogic thought and serve as a basis for a consensus on these positions.

\section{ПРИМЕЧАНИЯ}

REFERENCES

1. Gershunsky B. S. Education in the third millennium: the harmony of knowledge and faith. Moscow, 1997. 117 p. (In Russ.)

2. Gershunsky B. S. Mentality and Education. Moscow, 1996. 140 p. (In Russ.)

3. Gusinsky E. N., Turchaninova Y. I. Introduction to philosophy of education. Moscow, 2001. 224 p. (In Russ.)

4. Mikhailov F.T. Philosophy of education: its reality and prospects. Voprosy filosofii. Mocow, 1999. No 8. P. 92-118. (In Russ.)

5. Pedagogy: pedagogical theories, systems, technologies: Textbook. Moscow, 2000. 512 p. (In Russ.)

6. Rozanov V.V. The Twilight of education. Moscow, 1990. 624 p. (In Russ.)

7. Rozov N. S. Values in a problem world. Novosibirsk, 1998. P. 193-217. (In Russ.)

8. Shermis S. Philosophic foundations education. N.Y., 1969. 292 p.

Received: 27.11.2020 


\section{PHILOSOPHY OF EDUCATION AND PEDAGOGY: SUBJECT STATUS}

\section{ASHILOVA MADINA}

\author{
BEGALINOV \\ ALIBEK
}

\section{BEGALINOVA \\ KALIMASH}

\section{Keywords:}

education

philosophy of education

pedagogy

theory of education

foundations of education

applied philosophy

civilizational process

self-consciousness of person

individualization

socialization

subject of education
PhD in Philosophy, Associate Professor, Kazakh University of International Relations and Worldwide Languages named after Abylai Khan, Department of Media Communication, Almaty, Kazakhstan, madina.almatytv@gmail.com

Candidate of Philosophy,

Senior Lecturer, International University of Information Technology, Almaty, Kazakhstan, alibek557@inbox.ru

Doctor of Philosophy,

Professor,

Al-Farabi Kazakh National University, Department of Religious Studies and Cultural Studies, Almaty, Kazakhstan, kalima910@mail.ru

\section{Summary:}

The article deals with the features of the relationship between pedagogy and philosophy of education in the historical and genetic aspect. Various facets of their interaction caused by ideological and methodological approaches to the educational process are shown. Attention is drawn to the fact that the feature that distinguishes the philosophy of education from pedagogy is a holistic vision of education, the study of its problems in the most generalized and conceptual form. Various scientific approaches to pedagogy and philosophy of education are revealed, among which the situation developed within the framework of Soviet science is of particular interest, when pedagogy was understood as a "testing ground" for the application and approbation of philosophical ideas. Summarizing all the approaches, the authors come to the conclusion that the analysis of the education from the perspective of philosophy requires the recourse to pedagogy as a science, which explores the problems of education at a deep level, and from the perspective of pedagogy - the recourse to the philosophy of education, acting as a universal, conceptual, methodological, and ideological scientific knowledge. 